\title{
POLAND SENDROMU
}

\author{
Mehmet BAYRAMiçLi \\ Marmara Üniversitesi Tıp Fakültesi, Plastik Rekonstrüktif ve Estetik Cerrahi Anabilim Dalı, İstanbul, Türkiye \\ e-posta: mbayramicli@marmara.edu.tr \\ doi:10.5152/tcb.2011.38
}

Poland sendromu pektoralis majör ve minör kaslarının doğumsal yokluğuna eșlik eden aynı taraflı göğüs ve üst ekstremite deformiteleri bütününü tanımlar. Bununla birlikte sendromun tek sabit bulgusu "pektoralis majör kasının sternokostal parçasının yokluğu"dur. Bu sabit bulguya aynı tarafta pektoralis minör kasının yokluğu, meme dokusunun gelișmemesi, aksillada alopesi, 2. ile 5. arasındaki kaburgaların olmaması, latissimus dorsi, serratus anterior ve eksternal oblik kaslarının gelișmemiș olması gibi ilave bulgular eșlik edebilir (5). \%11-25 olguda aynı taraflı toraks çöküklüğü (Resim 1) ve/veya toraksta paradoksal hareket ve \%8 oranında akciğer herniasyonu görülebilir.

$\mathrm{Bu}$ anomali, 1840-1841 eğitim döneminde o zamanlar Guy's Hospital'da tıp fakültesi öğrencisi olan Alfred Poland'ın, üzerinde çalıștığı George Elt isimli 27 yașındaki eski mahkuma ait kadavradaki anatomik deformiteyi fark edip yayınlaması ile literatüre geçmiștir (1). Göğsünün sol tarafı ve sol kolu az gelișmiș, sol eli sağdan daha kısa ve parmakları az gelișmiș olan kadavranın diseksiyonunda, pektoralis majör ve minör kaslarının olmadığı serratus anterior kasının ise üstteki iki slip'i dıșında gelișmemiș olduğunu kaydeden Poland, kadavranın sağlığında sol kolunu göğsüne getirmekten aciz olduğunu da yazıya eklemiștir. Benzer göğüs deformitesini tanımlayan iki yayın bulunmasına karșın $(2,3)$. Poland deformiteyi eșlik eden eden bileșenleri ile birlikte ayrıntılı olarak tanımlamıștır. Buna rağmen yayın pek dikkat çekmemiș, daha sonraki dönemlerde benzeri olgularla ilișkisine değinilmemiș, bunun bașka araștırmacıların dikkatini çektiğine ilișkin bir kayıt da düșülmemiștir. Uzun bir süre sonra, 1962 yılında yine Guy's
Hospital'da Plastik cerrah olarak çalıșan Patrick Clarkson benzeri bir olguya rastladıktan sonra yaptığı literatür araștırması sırasında Poland'ın “Guy's Hospital Bulletin"de 1841 yılında yayınlanmıș olan olgu sunumuna rastlayınca yazarına atfen anomaliye "Poland" adını vermiștir (4).

Aynı taraftaki üst ekstremitede anomali görülmesi sıklığı yüksektir ve olguların \%13-56'sında değișik ağırlıklarda üst ekstremite anomalileri ana bulguya eșlik eder. Üst ekstremite anomalileri brakisindaktili formunda kısa ve yapıșık parmaklara ek olarak üst ekstremitenin kısalığı ile de ortaya çıkabilir (Resim 2). Bunlara ek olarak böbrek, ve omurga anomalileri ayrıca löseminin de eșlik eden sorunlar olabileceği kaydedilmektedir (6). İlginç olarak, yalnızca sindaktili yakınması ile bașvuran hastalarının genel muayeneleri sırasında yaklașık \%10 oranında Poland sendromu yakalanabilmektedir $(6,7)$.

Poland sendromu kadınlarda üçte bir oranında meme anomalisi bulgusu verir. Meme anomalisi basit meme hipoplazisinden amasti'ye kadar farklı ağırlıklarda olabilir (Resim 3). Meme bulgusunun silik olduğu durumlarda, 1/19000 gibi çok düșük oranda da olsa, radyolojik inceleme sırasında tesadüfen Poland sendromu yakalanabilmektedir (8).

Poland sendromunun insidansı $1 / 7000$ ile 1/100000 arasında bildirilmektedir (5). Erkeklerde kadınlara kıyasla 2-3 kat daha fazladır. Erkeklerdeki tek taraflı deformite göğüs sağ tarafında sola oranla 2 kat daha sık görülmektedir. Kadınlarda bir taraf tercihi yoktur (6). Literatürde iki taraflı tutulum olan tek olgu bildirilmiștir (9).

Etyolojisi hakkında kesin bir sonuca varılamamıș olmakla birlikte hamileliğin belirli dönemlerine ilișkin 


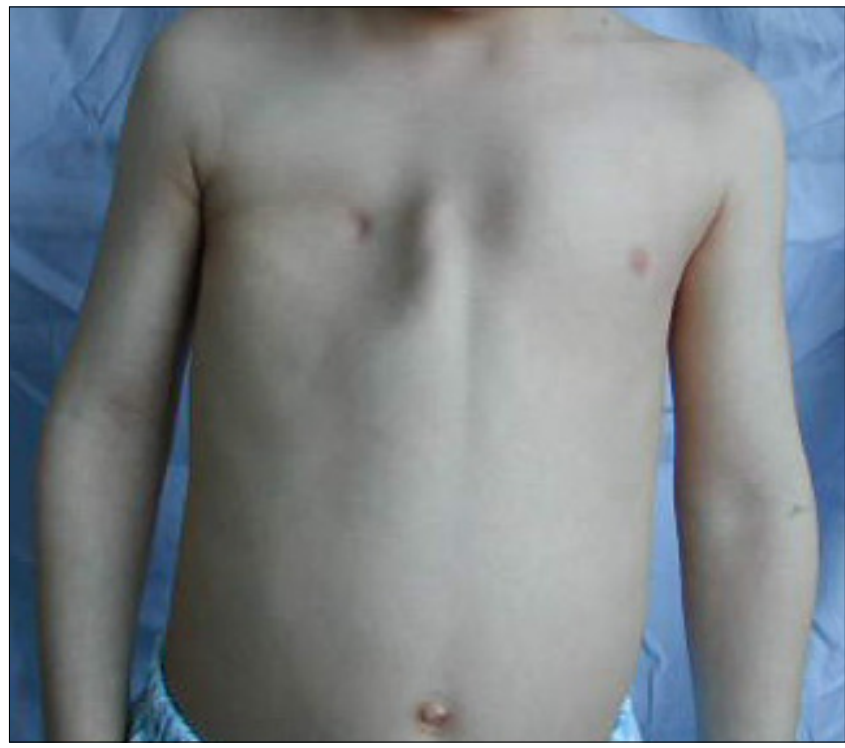

Resim 1. Poland sendromunda "pektoralis majör kasının sternokostal parçasının yokluğu"na aynı taraflı toraks çöküklüğü ve aynı taraftaki ekstremitenin gelișim yetersizliği sıklıkla eșlik eder (hastanın sağ akromiyon-olekranon mesafesi sola kıyasla kısadır)

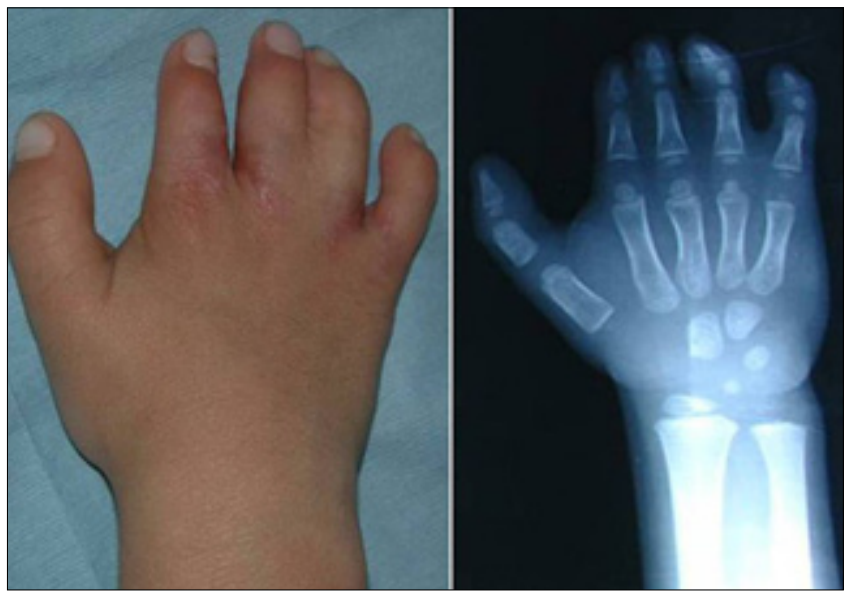

Resim 2. Kısa ve yapıșık parmaklarla belirgin olan "brakisindaktili" göğüs deformitesine sık eșlik eden el anomalisidir

iki temel hipotez taraftar bulmaktadır. Bunlardan ilki hamileliğin 3-4. haftalarında ortaya çıktığı düșünülen mezodermal plato hasarı veya gelișim yetersizliği (10) diğeri ise hamileliğin 6-7. haftalarında subklavyen ve vertebral sistemlerdeki kan akımının kesintiye uğramasıdır (11). Literatürde ailevi olgular çok nadir bildirilmiș olmakla birlikte "gecikmiș dominant germ hücresi mutasyonu” da üzerinde tartıșılan bir iddiadır (12).

\section{MUAYENE}

Poland sendromunda temel bulgu olan pektoralis majör kasının sternokostal parça yokluğu genellikle

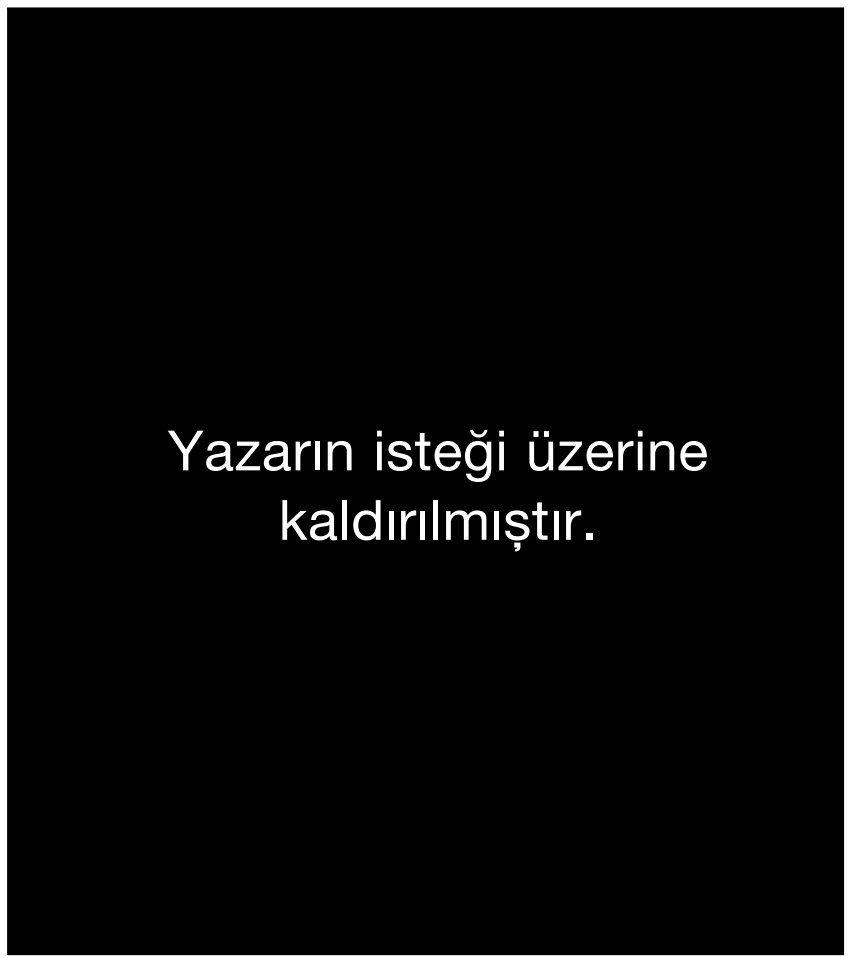

Resim 3. Poland sendromu kadınlarda sıklıkla meme anomalisi eșliğinde görülür. Meme ucu yokluğu ile belirgin bu amasti olgusu en ağır formlardan biridir

hasta veya ailesi tarafından fark edilir veya daha nadir olarak, temel bulgu fark edilmeyip meme hipoplazisi veya üst ekstremite deformitesi gibi eșlik eden bașka bulgu araștırılırken Poland sendromu tanısına ulașılabilir. Hastanın muayenesi sırasında eșlik eden bulguları ile birlikte deformitenin tam tanımını yapmak ve bunların hastaya getirdiği ișlevsel ve estetik yükü belirlemek önemlidir.

Toraks ve ekstremite inspeksiyonu çoğu zaman tanı koymak için yeterli olur. Ancak eșlik eden diğer anomalilerin belirlenmesi için göğüs deformitesinin ve kostaların palpasyonu, omuz-dirsek (akromiyon-olekranon mesafesi) (Resim 1), ön kol, el ve parmak uzunluklarının ölçümleri ve pektoralis majör, Latissimus dorsi ve serratus anterior kaslarının ișlev muayeneleri rutin olarak yapılmalıdır. Serratus anterior kasının yukarıdaki 5 slip'inden bazılarının veya tümünün yeteriz gelișimi "skapula instabilitesine" yol açar ve muayene sırasında kolaylıkla fark edilir.

Klinik muayeneye ek olarak düz toraks grafisi ve toraks BT incelemeleri çoğu zaman yeterlidir. Bu incelemelerde kosta eksiklikleri, skapulanın veya göğüs kafesinin bir tarafta daha küçük olması gibi bulgular kolaylıkla ortaya konabilir. Bunlara ekstremite anomalileri için gereken radyolojik incelemeler eklenebilir. Komplike rekonstrüksiyon planlanan hastalarda ise 3-D BT görüntüleri alınması önerilir (Resim 4). 


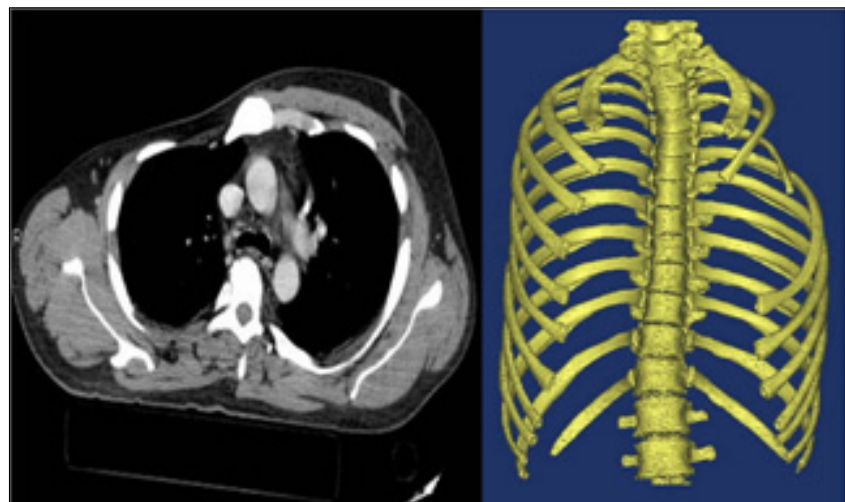

Resim 4. Düz toraks grafisi ve toraks BT incelemeleri çoğu zaman yeterli bilgi verir ancak komplike rekonstrüksiyon planlanan hastalarda 3-D BT görüntüleri gereklidir
Hastada var olan tüm deformite ve eksiklikler tanımlandıktan sonra klinik tablonun ağırlığı değerlendirilebilir. Bu noktada tabloyu hafif ve ağır form șeklinde kabaca bir kategoriye yerleștirmek mümkündür. Poland sendromunun temel bulgusu olan "pektoralis majör kasının sternokostal bölümünün yokluğu"na eșlik eden meme hipoplazisi ve meme ucu asimetrisi gibi günlük aktiviteleri ve spor yapmayı kısıtlamayan nispeten basit deformiteler "Hafif Form" olarak değerlendirilir. Buna karșın, günlük aktivitelerde kısıtlama yaratan kotsal, sternal ve müsküler eksiklikler ve üst ekstremitenin kıtlayıcı kas ve iskelet sistemi anomalilerinin temel bulguya eșlik ettiği olgular "Ağır Form" olarak değerlendirilir. Bu tür hastaların askerliğe elverișli olamayacakları da akılda tutulmalıdır (6).

\section{Yazarın isteği üzerine kaldırılmıștır.}

Resim 5. Kadınlarda meme ile ilgili sorunlar birkaç seanslı girișimler gerektirebilir. Poland sendromuna eșlik eden amastili hasta (solda). Meme lojuna doku genișletici yerleștirildikten sonra 12 haftalık șișirme ile implant cebi hazırlanması (ortada). Doku genișletici çıkartılıp sağ tarafa kalıcı meme implantı yerleștirilmesi ve aynı seansta simetri sağlamak için ptotik sol memenin küçültülüp dikleștirilmesi ișleminden 6 ay sonraki görünüm (sağda). Hastanın meme ucu yapımı (lokal flep ve tatuaj tekniği ile) ve anterior aksiller bölgeye yağ enjeksiyonları ile revizyonları planlanmıștır

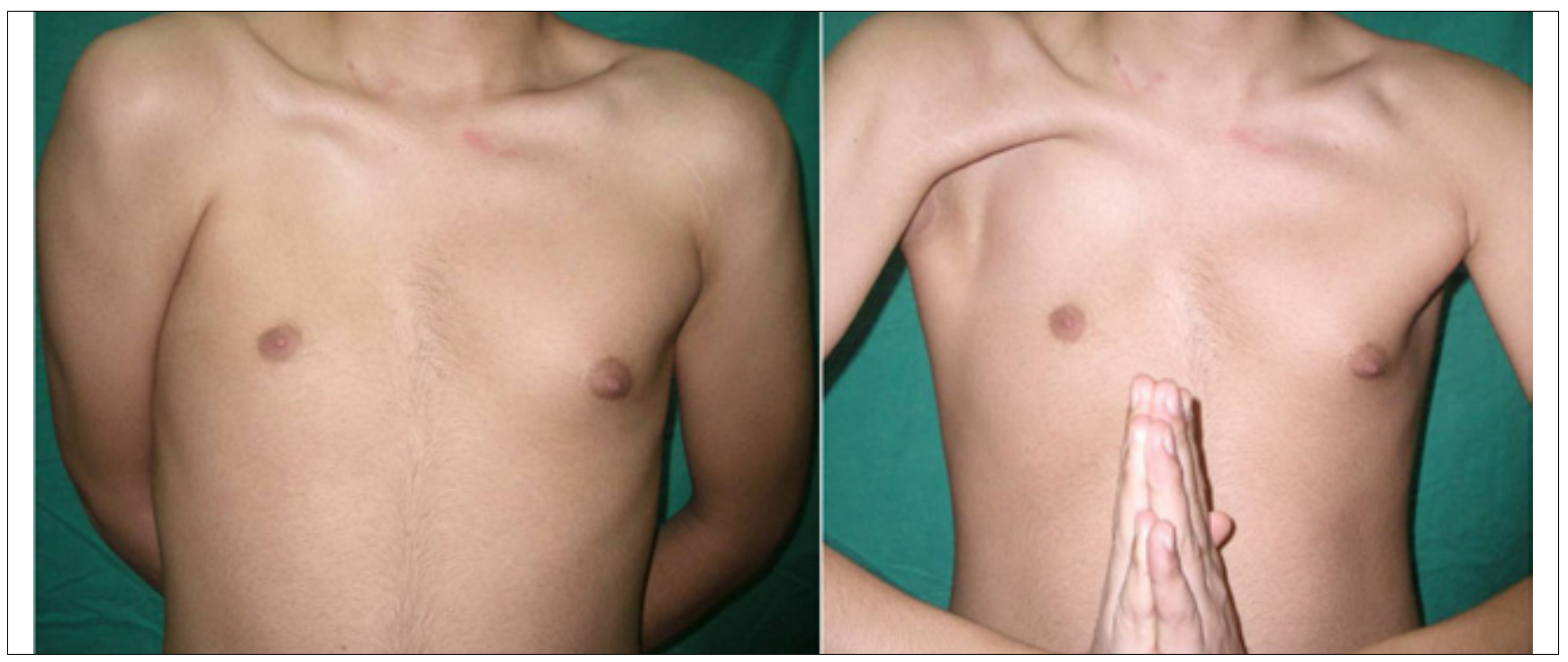

Resim 6. Hafif formda Poland sendromu. Latissimus dorsi kası normal ișlevinde 

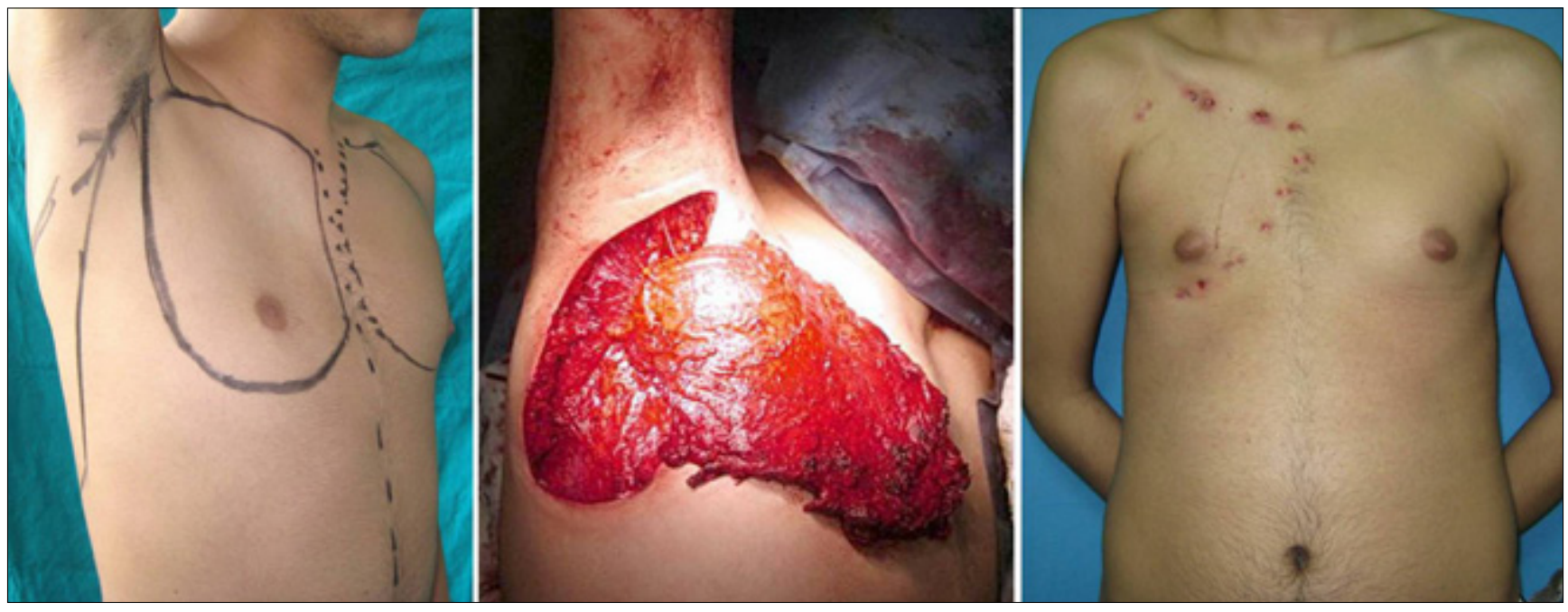

Resim 7. Pektoralis majör kası yerine Latissimus dorsi kas trasferi planlaması (solda). Arka aksiller hat üserindeki kesiden tüm latissimus dorsi kas flebinin hazırlanıp torakodorsal damarlar ve sinir pedikülü ile ada flebi olarak pektoral lojuna çevrilmesi (ortada). Latissimus dorsi kasının periferik tespitini yapan perkütan dikișler alındıktan hemen sonraki görünüm (ameliyat sonrası 3. hafta) (sağda)

Klinik tablonun ağırlığı hastanın ameliyat endikasyonları ve zamanlaması konusunda da belirleyicidir. Ameliyat planlaması sırasında iki önemli faktör değer tașır. Bunlardan ilki göğüs duvarı instabilitesinin ağırIığı, ikincisi ise deformitenin hastaya verdiği rahatsızlıktır. Göğüs duvarı instabilitesi olan hastalarda sorun daha çok ișlevsel olduğu için tanı konduktan sonraki en kısa sürede ameliyat planlaması yapmak gereklidir. Buna karșlık ișlevsel sorunun öne çıkmadığı olgularda estetik kaygı belirleyicidir ve ameliyat planlamasının ergenlik sonrasında yapılması daha gerçekçi bir yaklașım olur.

\section{CERRAHI SEÇENEKLER}

Poland sendromunun ișlevsel ve estetik sorunlarına yaklașımlar hem zamanlama hem de teknik olarak farklıdır. Göğüs kafesindeki kosta eksiklikleri ve göğüs kafesinin paradoksal hareketleri gibi durumlarda iskelet sistemi stabilitesini ve göğüs kafesinin koruyucu yapısı güçlendirmeye yönelik girișimler önceliklidir. Bir kosta greftinin uzunlamasına iki parça haline getirilip (split kosta grefti) eksik kostaların onarımlarında kullanılması, sternuma transvers osteotomi yapılarak eğriliğinin düzeltilmesi, kosta greftlerinin yanı sıra "marlex mesh" ile stabilizasyonun güçlendirilmesi veya göğüs duvarındaki defektin "marlex mesh sandvich" tekniği ile onarılması olgudaki sorunun ağırlığına göre seçilebilecek etkili yöntemlerdir (5). Bu onarım yöntemleri ilave olarak latissimus dorsi kas transpozisyonu ile de desteklenebilir.

Poland sendromundaki estetik sorunlar erkek ve kadın hastalarda meme açısından faklılık gösterir.

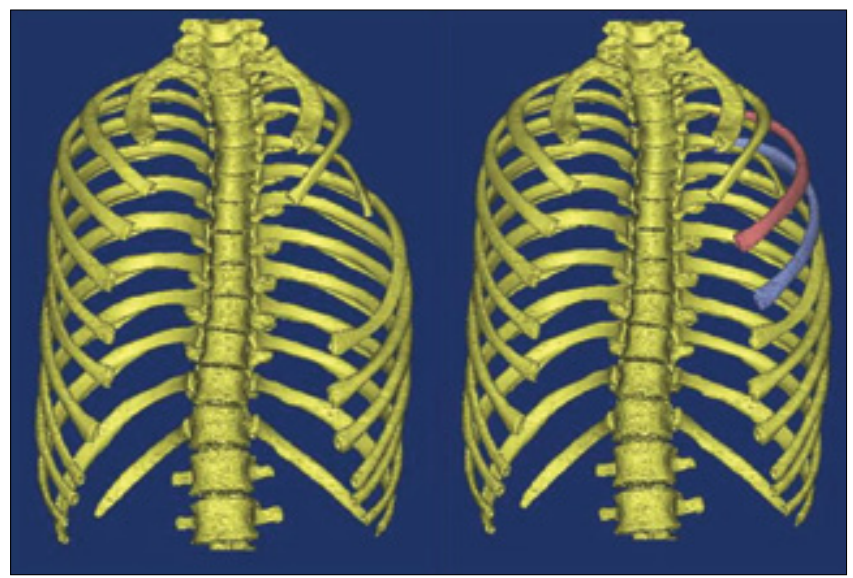

Resim 8. Üç boyutlu BT rekonstrüksyonu sonrası ayrıntılı olarak ortaya konan deformite üzerinde bilgisayar programı ile eksikler tamamlanır. Kosta greftleriyle onarılmıș toraks duvarı (sağda)

Estetik amaçlı ameliyatlar ișlevsel sorunlar çözümlendikten sonraki bir dönemde daha kolay planlanır. Ortada girișim gerektiren ișlevsel bir sorun yoksa hastanın ergenlik döneminde bedensel gelișimini büyük ölçüde tamamlaması ve dahası kendi bedensel algısının olgunlașması tercih edilir. Estetik sorunların çözümü için ya otojen doku transferi, ya hastaya özgü silikon implant (lar), ya da her iki çözümü bir arada kullanan birden fazla seanslı girișimler önerilebilir. Kadınlarda göğüs duvarı deformitesinin yanı sıra meme ile ilgili sorunlar da dikkate alınması gerektiği için birkaç seanslı kombine girișimler daha sıktır (Resim 5). Son yıllarda yağ enjeksiyonlarına yaklașımın değișmesi ile bu yöntemin ana veya yardımcı tercih olarak kullanımının arttığı görülmektedir (13). 


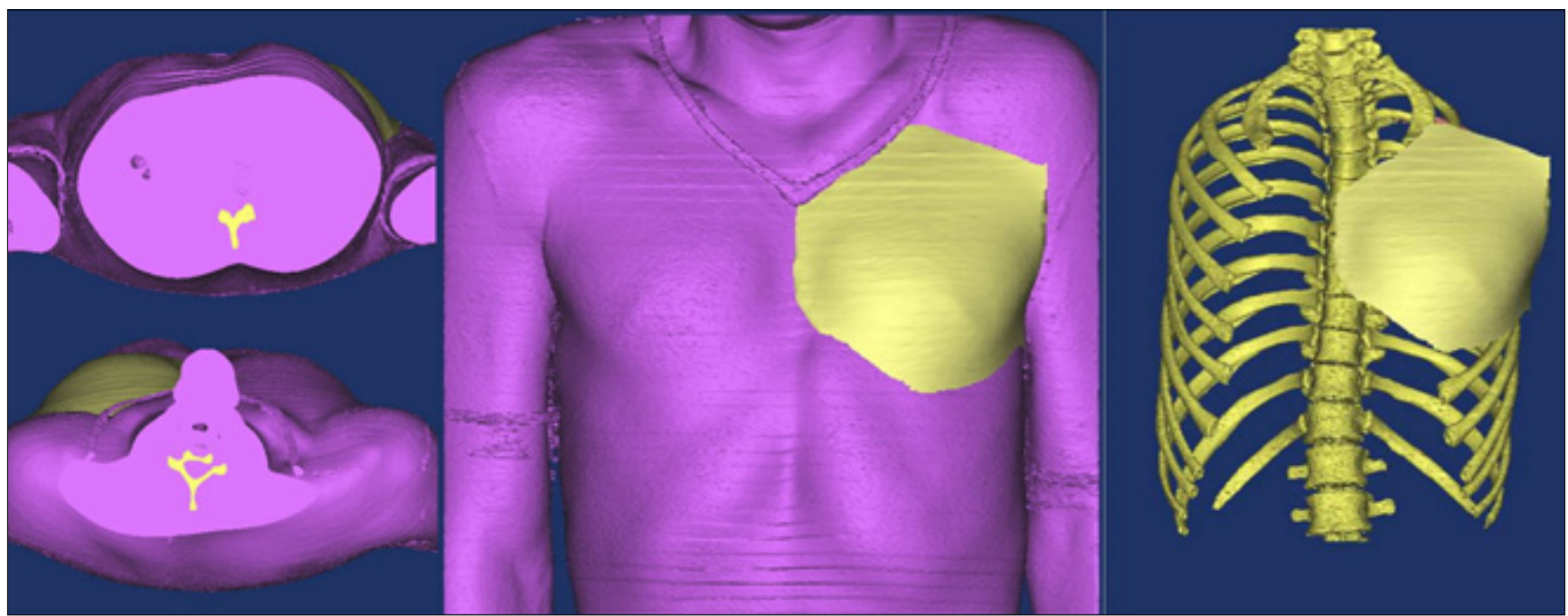

Resim 9. Göğüs duvarındaki kosta eksikliği giderildikten sonra yumușak doku eksiği karșı toraks yarımına göre tamamlanır

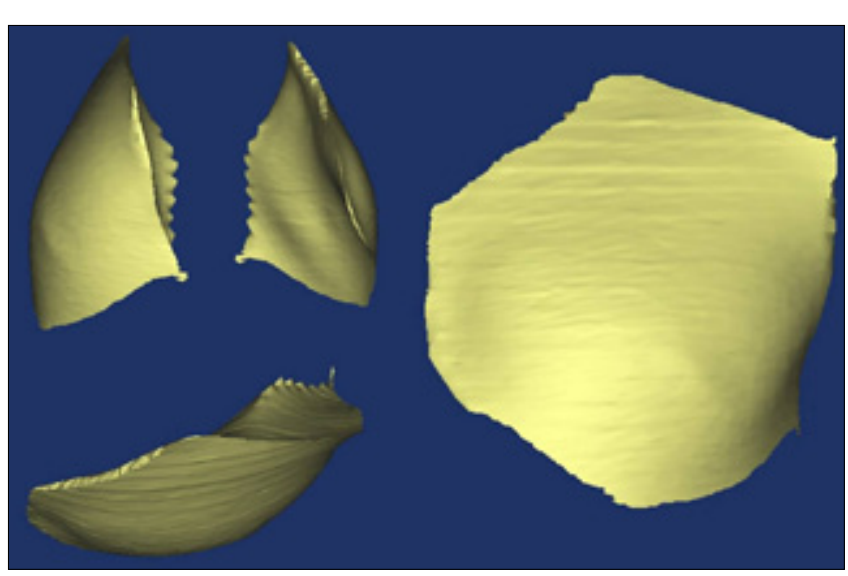

Resim 10. Deformiteyi düzeltmek için gereken parça bilgisayar programı ile üç boyutlu olarak belirlendikten sonranormal ölçülerdeki üç boyutlu kalıp hazırlanıp üretici firmaya yollanır
Göğüs duvarı deformitesinin düzeltilmesi veya eksik olan pektoralis majör kasının ișlevsel bir kas transferi ile onarılması için hastanın kendi vücudundan hazırlanıp serbest veya pediküllü flep șeklinde kullanılabilecek seçenekler mevcuttur. Bunlardan en sık ve etkili kullanılabilen transfer latissimus dorsi kasının torakodorsal arter ve ven pedikülü üzerinde ve torakodorsal sinir korunarak ada flebi șeklinde pektoralis majör kası yerine aktarılmasıdır. Latissimus dorsi pektoralis majör'e benzer biçimde "yelpaze" șekilli bir kas olduğu için geniș distal bölümü sternal kenara yayılıp tendonu ise humerus arkasından ayrııp humerus ön kenarına tespit edilerek iyi bir onarım seçeneği sunar (Resim 6 ve 7). Ancak hastadaki anomaliler arasında latissimus dorsi kası da gelișmemișse veya hastanın ișlevsel olarak bu kasın feda

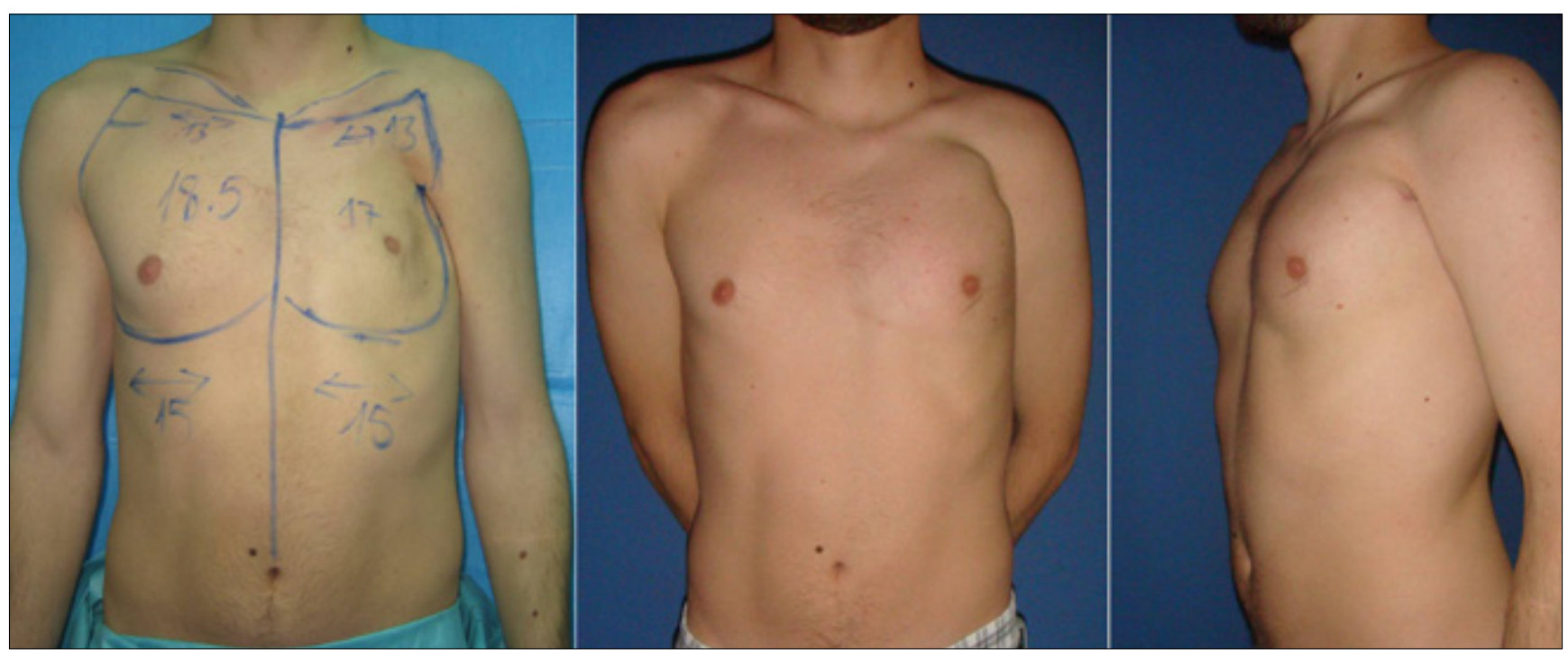

Resim 11. Hastaya özel implantla rekonstrüksiyon. Ameliyat öncesi planlama (solda). Ameliyat sonrası altıncı ayda karșıdan görünüm (ortada) Ameliyat sonrası altıncı ay sol oblik görünüm (sağda) 


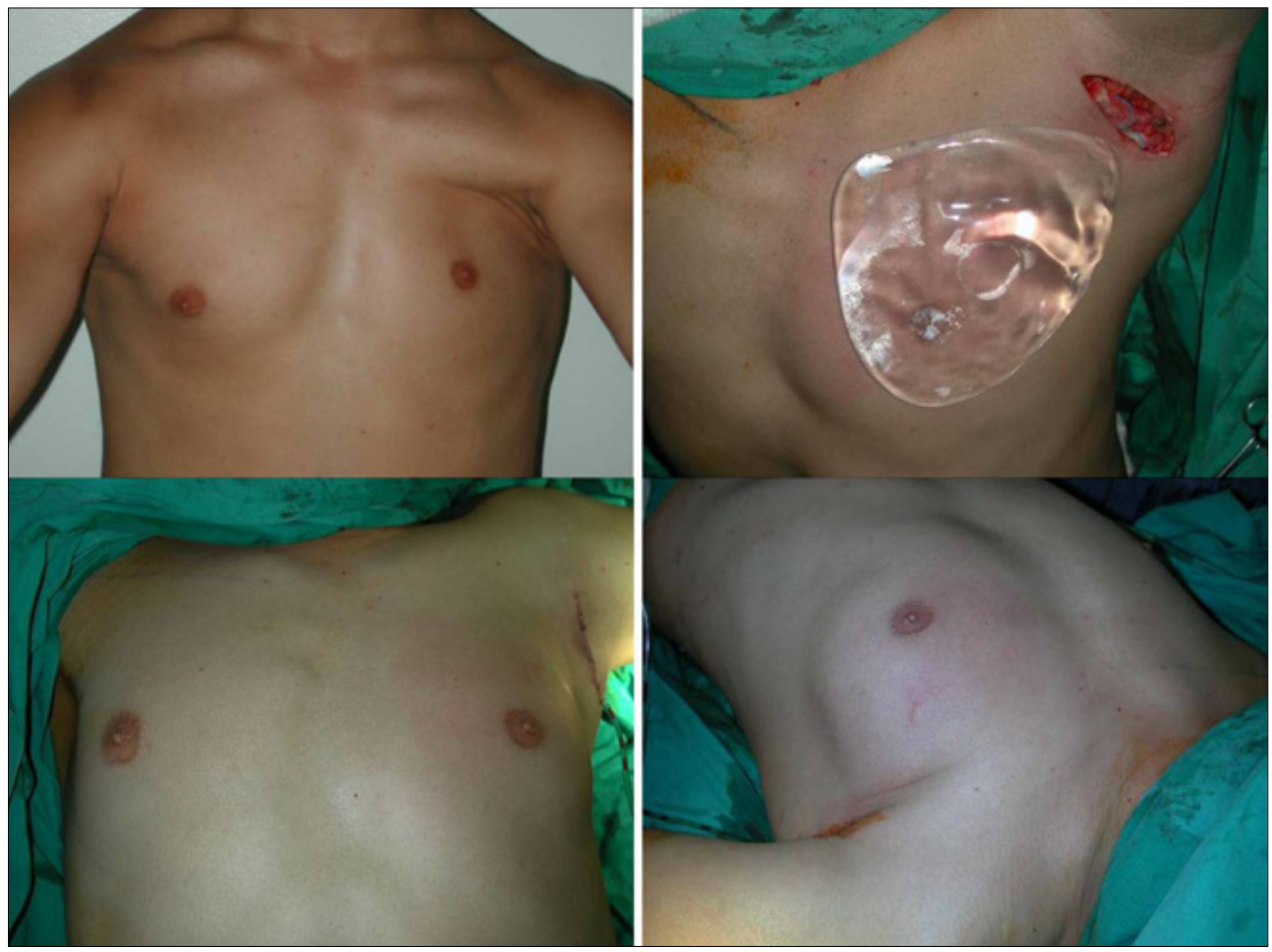

Resim 12. İmplantın konulacağı pektoral bölge cebi koltuk altından yapılan $6 \mathrm{~cm}$ 'lik kesiden hazırlanabilir ve implant buradan yerleștirilebilir

edilmesine engel bir durumu varsa (koltuk değneği kullanımı veya spor gibi) bu seçenek doğal olarak ortadan kalkacaktır. Bu durumda ișlevsel transferi tercihi zorlanırsa rektus abdominis kasının serbest transferi düșünülebilir. Ancak bu rektus'un segmenter innervasyon özelliği planlamada dikkate alınmalıdır.

İmplantlar, onarımda en sık bașvurulan, cerrahi teknik olarak da kolay ve hızlı seçenekler sunar. Ancak Poland sendromunun hastaya özel değișken bileșenleri yüzünden standart olarak önceden hazırlanmıș implant serileri mevcut değildir. Bu nedenle implant kullanıması gerektiğinde hastanın üzerinde elle bir alçı kalıp hazırlanması veya bilgisayar programı ile üç boyutlu bir tasarım yapılması gereklidir (Resim 8-10). Hastaya göre hazırlanan bu kalıp üretici firmaya gönderilerek yarı sert veya içi jel dolu silikon implant üretilir ve ancak ondan sonra hasta opere edilerek implant yerleștirilir (Resim 11).

İmplantların konulacağı pektoral bölge cebi genellikle koltuk altından yapılan 6-8 cm'lik kesilerden ve ıșıklı ekartörler yardımı ile kolayca hazırlanabilir ve buradan implantlar yerleștirilir (Resim 12). Bununla birlikte tek bașına aksiler insizyonla diseksiyonda zorluk olursa meme altı insizyonları da tercih edilebilir.

\section{SONUÇ}

Poland sendromu değișken prezentasyonlu bir deformiteler grubu olarak karșımıza çıkar. Pektoralis majör kasının sternokostal parçasının yokluğu temel bulgu olmasına karșın eșlik eden deformitelerle birlikte ortaya çıkan tablo hastanın ișlevsel ve estetik sorunlarını belirler. Torakstaki deformitelerin yarattığı ișlevsel sorunlar eğer ağırsa öncelikli olarak ve zaman geçirmeden çözülmelidir. İșlevsel sorun yaratmayan estetik sorunlar, hastanın bedensel algısı, mesleki ve sosyal etkinliklerinin yönlendirmesi ile belirginleșir. Bu nedenle hastaya göre çözüm üretilmeli, hastanın estetik ve ișlevsel kaygılarına göre tekniği seçimi yapılmalıdır. 


\section{KAYNAKLAR}

1. Poland A. Deficiency of the pectoral muscles. Guys Hosp Rep 1841:6;191-3.

2. Lallemand LM. Ephemerides. Medicales de Montpellier 1826;1:144-7.

3. Froriep R. Beobachtung eines Falles von Mangel der Brustdrüse. Notizen Gebiete Natur Heilkunde 1839;10: 9-14.

4. Clarkson P. Poland's syndactyly. Guys Hosp Rep 1962;111:335-46.

5. Fokin AA, Robicsek F. Poland's syndrome revisited. Ann Thorac Surg 2002;74:2218-25. [Crossref]

6. Knoetgen J, Johnson CH, Arnold PG. Reconstruction of the Chest. Plastic Surgery. (Stephen J Mathes, ED; Vincent R. Hentz-2nd Ed.) Vol VI, Saunders Elsevier 2006, pp: 411-537.

7. Al-Qattan MM. Classification of hand anomalies in Poland's syndrome. Br J Plast Surg 2001;54:132-6. [Crossref]
8. Perez Aznar JM, Urbano J, Garcia Laborda E, Quevedo Moreno P, Ferrer Vergara L. Breast and pectoralis muscle hypoplasia: A mild degree of Poland's syndrome. Acta Radiol 1996;37: 759-62. [Crossref]

9. Karnak I, Tanyel FC, Tunçbilek E. Bilateral Poland anomaly. Am J Med Genet 1998;75:505-7. [Crossref]

10. Bamforth JS, Fabian C, Machin G, Honore L. Poland anomaly with limb body wall disruption defect: case report and review. Am J Med Genet 1992;43:780-4. [Crossref]

11. Bouvet JP, Leveque D, Bernetieres F, Gros JJ. Vascular origin of Poland's syndrome? A Comperative rheographic study of the vascularization of the arms in eight patients. Eur J Pediatr 1978;128:17-26. [Crossref]

12. David TJ. Familial Poland anomaly. J Med Genet 1982;19:293-6. [Crossref]

13. Pinsolle V, Chichery A, Grolleau J-L, Chavoin JP. Autologous fat injection in Poland's Syndrome. JPRAS 2008;61:784-91. [Crossref] 